\title{
Stress-induced apoptosis is impaired in cells with a lysosomal targeting defect but is not affected in cells synthesizing a catalytically inactive cathepsin D
}

\author{
C Tardy ${ }^{1}$, J Tyynelä ${ }^{2}$, A Hasilik ${ }^{3}$, Levade $^{1}$ and \\ N Andrieu-Abadie ${ }^{*, 1}$ \\ 1 INSERM U466, Institut Louis Bugnard, Centre Hospitalier Universitaire de \\ Rangueil, Toulouse, France \\ 2 Institute of Biomedicine/Biochemistry, Biomedicum Helsinki, University of \\ Helsinki, Haartmaninkatu 8, FIN-00014 Helsinki, Finland \\ 3 Institute of Physiological Chemistry, Philipps-University Marburg, Karl-von- \\ Frisch-Str.1; D-35033 Marburg, Germany \\ * Corresponding author: N Andrieu-Abadie, INSERM U466, Institut Louis \\ Bugnard, Centre Hospitalier Universitaire de Rangueil, 1 Avenue Jean \\ Poulhès, TSA 50032, 31059 Toulouse Cedex 9, France. Tel: 33-561-32-20-60; \\ Fax: 33-561-32-20-84; E-mail: nandrieu@toulouse.inserm.fr
}

Received 30.1.03; revised 17.4.03; accepted 18.4.03

Edited by M Piacentini

\begin{abstract}
The role of cathepsin $D$ in stress-induced cell death has been investigated by using ovine fibroblasts exhibiting a missense mutation in the active site of cathepsin D. The cathepsin D (lysosomal aspartic protease) deficiency did not protect cells against toxicity induced by doxorubicin and other cytotoxic agents, neither did it protect cells from caspase activation. Moreover, the cathepsin D inhibitor, pepstatin A, did not prevent stress-induced cell death in human fibroblasts or lymphoblasts. The possible role of lysosomal ceramide or sphingosine-mediated activation of cathepsin $D$ in apoptosis was also excluded by using human cells either overexpressing or deficient in acid ceramidase. However, a normal lysosomal function seems to be required for efficient cell death, as indicated by the finding that fibroblasts from patients with mucolipidosis II were partially resistant to staurosporine, sphingosine and TNF-induced apoptosis, suggesting a key role of lysosomes in cell death.

Cell Death and Differentiation (2003) 10, 1090-1100. doi:10.1038/ sj.cdd. 4401272
\end{abstract}

Keywords: apoptosis; cathepsin D; lysosome; ceramide; I-cell disease

Abbreviations: ALLN, $\mathrm{N}$-acetyl-leu-leu-norleucinal; AMCA-Hb, 6-[(7-amino-4-methylcoumarin-3-acetyl) amino] hexoid acid-hemoglobin; ara-C, 1- $\beta$-D-arabinofuranosylcytosine; CA-074 Me, [L-3-trans-propylcarbamoyl)oxirane-2-carbonyl]-L-isoleucyl-L-proline methyl ester; CONCL, congenital ovine neuronal ceroid lipofuscinosis; DAPI, 4',6-diamidino-2-phenylindole; Ac-DEVDAMC, Ac-Asp-Glu-Val-Asp-7-amido-4-methylcoumarin; E64, trans-epoxysuccinyl-L-leucylamido(4-guanidino)-butane; MTT, 3-(4,5-dimethylthiazol-2-yl)-2,5-diphenyltetrazolium bromide; TNF- $\alpha$, tumor necrosis factor- $\alpha$; zFF-fmk, benzyloxycarbonyl- phe-phe-fluoromethylketone; zFR-AMC, benzyloxycarbonyl-pheArg-7-amido-4-methylcoumarin; zRR-AMC, benzyloxycarbonylarg-arg-7-amido-4-methylcoumarin; zVAD-fmk, benzyloxycarbonyl-Val-Ala-DL-Asp-fluoromethylketone

\section{Introduction}

Lysosomes contain numerous enzymes for degradation of proteins, nucleic acids, polysaccharides, lipids and their conjugates. Among their proteolytic enzymes, the cathepsins belong to three distinct catalytic types based on the active site amino acid: the serine (cathepsins $A$ and $G$ ), the cysteine (cathepsins $\mathrm{B}, \mathrm{C}, \mathrm{H}, \mathrm{K}, \mathrm{L}, \mathrm{S}$ and $\mathrm{T}$ ) and the aspartic (cathepsins $D$ and E) proteases. ${ }^{1}$ Cathepsins are synthesized as pre-proenzymes and their activation involves proteolytic processing. ${ }^{2}$ They are widely distributed in normal tissues ${ }^{3}$ and are involved in a variety of physiological processes., ${ }^{4,5}$ Their importance is highlighted by the occurrence of lysosomal diseases characterized by the defect in cathepsin activity. ${ }^{6-12}$ Recent studies have suggested that some lysosomal cathepsins may play an active role in transducing the death signal triggered by cytotoxic drugs. $^{13-16}$

For example, the concept that cathepsin D acts as a cell death mediator has been supported by several observations: (i) fibroblasts from cathepsin D-deficient mice were found to be more resistant to doxorubicin, etoposide or $\alpha$-tocopheryl succinate-induced apoptosis than their normal counterparts; ${ }^{17,18}$ (ii) expression of cathepsin D antisense constructs in HeLa cells was described to inhibit interferon-gamma- and Fas/APO-1-induced cell death; ${ }^{19}$ (iii) ectopic expression of cathepsin D was shown to induce HeLa cell death in the absence of any external stimulus. ${ }^{19}$ Similarly, PC12 cells overexpressing cathepsin $\mathrm{D}$ died more rapidly than wild-type cells in serum-deprived culture, ${ }^{20}$ and microinjection of cathepsin $D$ into the cytosol of human fibroblasts caused apoptosis. $^{21}$

Further support that cathepsin D might be involved in cell death signaling came from studies in which pepstatin $A$, an aspartic protease inhibitor, was reported to block cell death induced by interferon-gamma, Fas/APO-1, ${ }^{19}$ tumor necrosis factor- $\alpha(\mathrm{TNF}-\alpha),{ }^{22}$ camptothecin, ${ }^{23}$ naphthazarin, ${ }^{24,25}$ the synthetic retinoid CD $437^{26}$ or hydrogen peroxide. ${ }^{27}$

However, this concept has been challenged by very recent reports that have demonstrated that cathepsin $D$ is not directly implicated in the cell death machinery. Indeed, it has been reported that pharmacological inhibition of cathepsin $D$ activity did not suppress Bid cleavage nor procaspase-9 and -3 activation induced by photodynamic therapy in murine hepatoma cells. ${ }^{28}$ Moreover, pepstatin A did not protect serum-deprived PC12 cells from death. ${ }^{29}$ Rather, pepstatin A 
triggered apoptosis in human neuroblastoma cell lines, demonstrating that lysosomal cathepsin $D$ is not positively connected with cell death. ${ }^{30}$ Furthermore, it has also been observed in L929 fibroblasts that inhibition of cathepsin D did not prevent apoptosis induced by etoposide, although it did when induced by TNF- $\alpha$. In this model, lysosomal integrity was preserved and cathepsin $D$ remained confined to vesicular structures in apoptotic cells treated with either TNF- $\alpha$ or etoposide. $^{22}$

Finally, the fact that mitogenic agents (e.g., insulin-like growth factor-I, transforming growth factor alpha and epidermal growth factor) can induce cathepsin $D$ gene expression in human breast cancer cells transiently transfected with a construct containing a cathepsin $D$ gene promoter insert, ${ }^{31}$ underlines the physiological importance of cathepsin D mitogenic activity. The various in vitro observations, as well as data collected in animal models, point to the complex functions of cathepsin D in apoptotic cell death, which remain to be elucidated.

To assess the yet ill-defined role of cathepsin D in apoptosis, we have used fibroblasts from cathepsin Ddeficient sheep. These animals exhibit a neurological disorder, congenital ovine neuronal ceroid lipofuscinosis (CONCL), due to a single nucleotide mutation in the active site of cathepsin $D$, leading to an enzymatically inactive but stable protein. ${ }^{12}$ The susceptibility of CONCL cells to various apoptotic inducers was compared to that of cells from healthy sheep, as were the cell death-signaling pathways. Here, we show that stress-induced cell death was similar in normal and cathepsin D-deficient cells. Further, an inhibitor of caspases prevented apoptosis but did not affect the activity of cathepsin D in control cells. In contrast to cathepsin Ddeficient cells, I-cell-disease fibroblasts, characterized by a general deficiency in lysosomal hydrolases, partially resisted stress agents, indicating the importance of lysosomes in cell death.

\section{Results}

\section{Toxicity of doxorubicin in cathepsin D-deficient cells}

To examine the role of cathepsin D in doxorubicin-induced cell death, we used a genetic model, that is, fibroblasts (CONCL) presenting a missense mutation in the active site of cathepsin D. As compared to control fibroblasts isolated from healthy sheep, the apparent cathepsin D enzymatic activity in CONCL cells as estimated using AMCA-Hb as substrate was $5 \%$ (Figure 1a). This activity, unlike that in the control, was not sensitive to pepstatin $A$, and was therefore, due to proteases other than cathepsin D. In contrast, the activities of other lysosomal enzymes ( $\beta$-galactosidase, $\beta$-hexosaminidase and acid sphingomyelinase) in cathepsin D-deficient cells were not different from the control (data not shown). In addition, a comparison of SV40-transformed and untransformed fibroblasts revealed that cathepsin $D$ activity was decreased when the oncoprotein p53 is inactivated, in agreement with previous reports demonstrating that cathepsin $D$ is a p53-regulated gene. $^{32}$ Indeed, although the precise mechanism of SV40 transformation is not yet fully elucidated, large $T$ antigen is

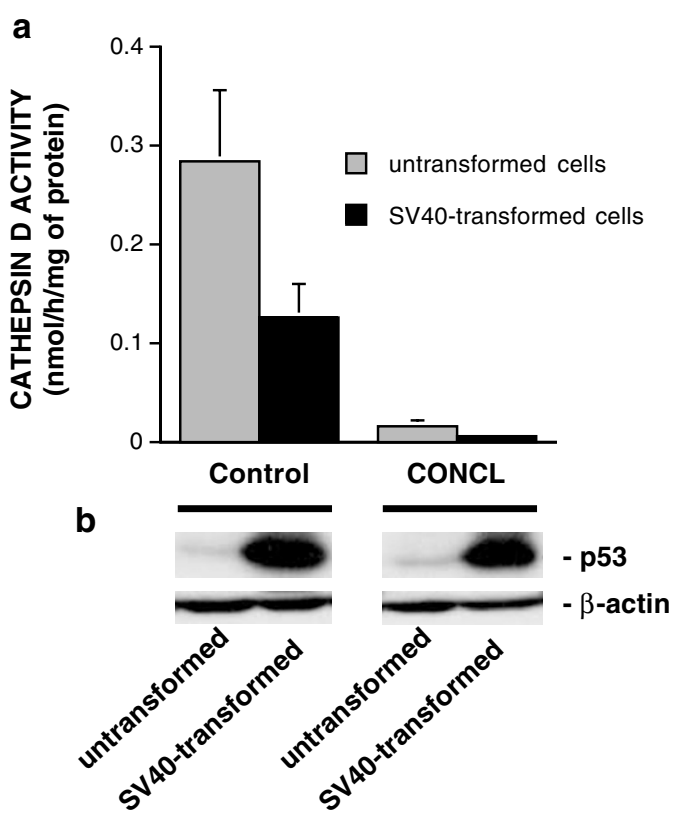

Figure 1 Cathepsin $D$ enzymatic activity is deficient in untransformed and SV40-transformed CONCL fibroblasts. (a) Cathepsin D enzymatic activity in untransformed fibroblasts isolated from control and CONCL sheep and in SV40transformed fibroblasts. Results are means \pm S.E. of three to six independent determinations. Activities in CONCL cells are significantly different from those of control cells $(P<0.005)$. (b) Western blot analysis of p53 protein expression in untransformed and SV40-transformed ovine fibroblasts. Samples were loaded onto a $12.5 \%$ SDS-polyacrylamide gel

known to allow the cells to bypass the G1 block of the cell cycle, most probably by inhibiting p53..$^{33,34}$ As shown in Figure 1b, SV40-transformed fibroblasts exhibited a strong expression of p53 as compared to untransformed cells, supporting the widely accepted view of p53 stabilization and inactivation in SV40-transformed cells. ${ }^{33,35}$

The cytotoxic effect of doxorubicin on ovine cells was doseand time-dependent. Cell viability was reduced by $\sim 40 \%$ after $48 \mathrm{~h}$ exposure to $1 \mu \mathrm{M}$ doxorubicin (Figure $2 \mathrm{a}$ and b). Under all conditions tested, cathepsin $D$ deficiency had no effect on anthracycline-induced cell death, whereas the cytotoxic effect of the drug was abolished in cells preincubated with the broad caspase inhibitor benzyloxycarbonyl-Val-Ala-DL-Asp-fluoromethylketone (zVAD-fmk) (Figure 2b). This suggested that cell death occurred in a caspase-dependent way. As illustrated in Figure 2c, SV40-transformed fibroblasts were more sensitive to the lethal effect of doxorubicin than untransformed cells, further suggesting that cathepsin D activity is not (directly) correlated with the extent of cell death.

The sensitivity of CONCL cells to anthracyclines was further investigated by examining the rate of apoptosis following doxorubicin treatment. As shown in Figure $3 \mathrm{a}, 48 \mathrm{~h}$ treatment with doxorubicin led to a significant increase in DNA fragmentation (2.5- and 3-fold elevation in control and CONCL cells, respectively, for $1 \mu \mathrm{M}$ doxorubicin). Moreover, caspase activity, as measured by the cleavage of the fluorogenic tetrapeptide substrate DEVD, increased in ovine cells within $8 \mathrm{~h}$, peaking at $12 \mathrm{~h}$ post-treatment (Figure $3 \mathrm{~b}$ ). Of interest 
a

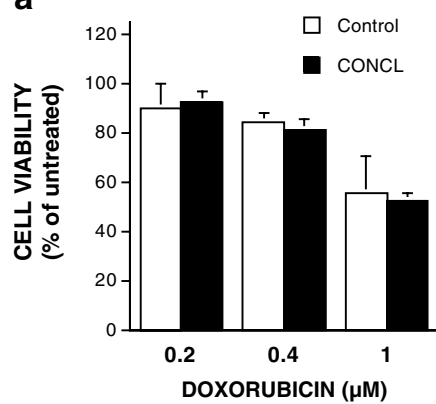

b

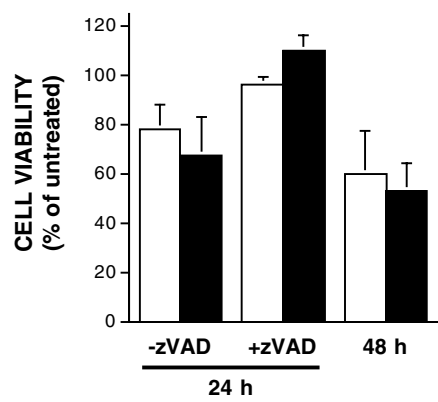

C

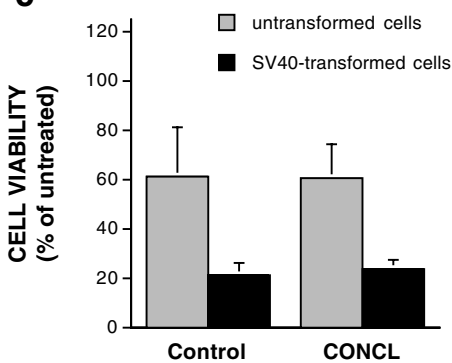

Figure 2 The deficiency in cathepsin D activity does not protect ovine cells against toxicity of doxorubicin. (a) SV40-transformed control and CONCL fibroblasts were incubated for $48 \mathrm{~h}$ in medium containing $1 \% \mathrm{FCS}$ in the presence of the indicated concentrations of doxorubicin. Cell viability was assessed by MTT assay, by comparing untreated and doxorubicin-treated cells. Results are means + S.E. of five to nine independent determinations. (b) SV40-transformed cells were incubated for the indicated times with $1 \mu \mathrm{M}$ doxorubicin in the presence or absence of $25 \mu \mathrm{M}$ zVAD-fmk, added to the cell culture medium $2 \mathrm{~h}$ prior to addition of doxorubicin. Results are means + S.E. of four to five independent determinations. Cell viability in the presence of zVAD-fmk is significantly different from that in the absence of the inhibitor $(P<0.05)$. (c) Untransformed and SV40-transformed cells were incubated for $72 \mathrm{~h}$ in $1 \%$ FCS with $1 \mu \mathrm{M}$ doxorubicin. Data are means $+\mathrm{S}$.E. of three to six independent experiments

was the finding that all these anthracycline-induced apoptotic events were not prevented in cathepsin D-deficient cells.

\section{Doxorubicin-induced cathepsin $D$ activation is not caspase dependent}

We next examined how doxorubicin treatment affected cathepsin D activity and protein expression. As seen in Figure $4 a$, treatment of ovine control cells with the chemother-
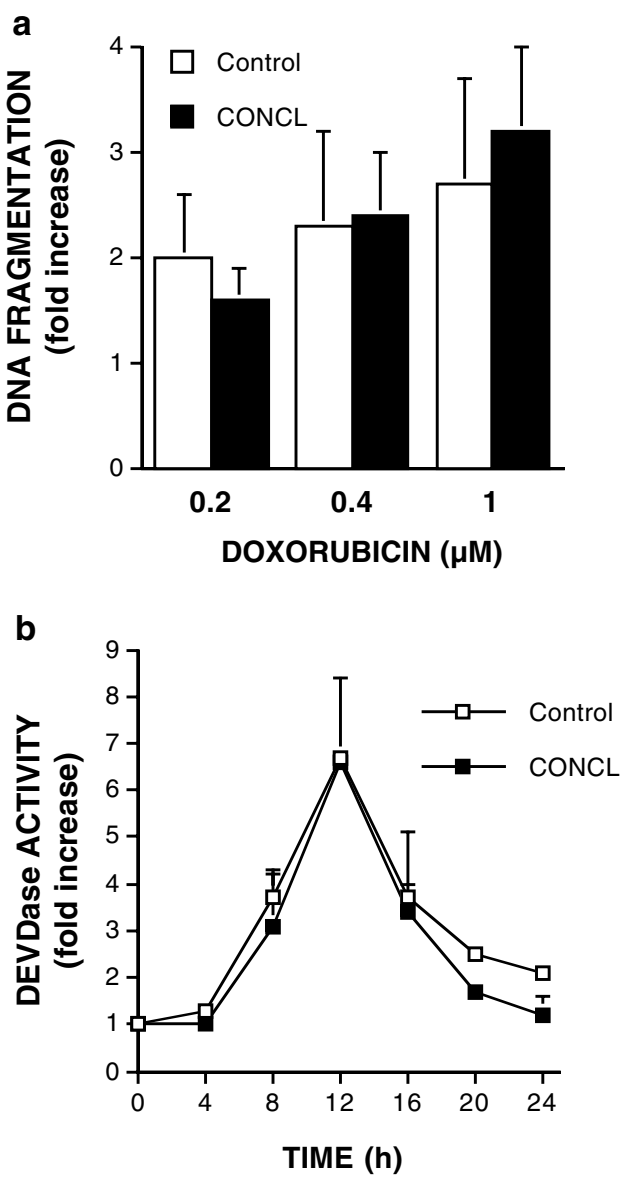

Figure 3 Effect of the deficiency in cathepsin D activity on doxorubicin-induced DNA fragmentation and caspase activation. (a) SV40-transformed control or CONCL fibroblasts were incubated for $48 \mathrm{~h}$ in $1 \% \mathrm{FCS}$ in the presence of the indicated concentrations of doxorubicin. Quantitative DNA fragmentation was determined by the spectrofluorometric DAPI procedure. Results are means \pm S.E. of 4-10 independent determinations and are expressed relative to untreated cells. (b) SV40-transformed cells were incubated in $1 \%$ FCS with $1 \mu \mathrm{M}$ doxorubicin for the indicated times. Cells were then harvested and DEVDase activity was determined as described in the Materials and Methods section. Data are means $\pm S$.E. of three independent experiments

apeutic drug stimulated an increase in cathepsin D activity, in agreement with the observed increase of cathepsin D expression in adriamycin-treated leukemic cells. ${ }^{17}$ This phenomenon started $4 \mathrm{~h}$ after cell treatment and was increased several-fold at $24 \mathrm{~h}$. Moreover, Western blot analysis revealed that this doxorubicin-induced increase in cathepsin $\mathrm{D}$ activity was accompanied by increased levels of the cathepsin $\mathrm{D}$ active, heavy chain $(31 \mathrm{kDa})$ form in control cells (Figure $4 b$ )

To further explore the molecular events that lead to cathepsin D activation after doxorubicin treatment, and because activation of cathepsins could be related to caspase processing, we investigated the role of caspases. To this end, cathepsin D activity was monitored in control ovine cells in the presence or absence of ZVAD-fmk. The cells were preincubated for $2 \mathrm{~h}$ with $\mathrm{zVAD}$-fmk before doxorubicin addition. zVAD-fmk did not block the doxorubicin-induced increase in cathepsin D activity (Figure 4a), whereas the cytotoxic effect 
a

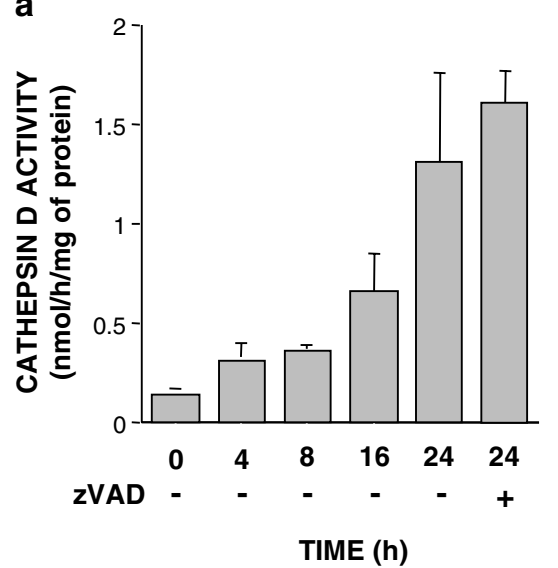

b

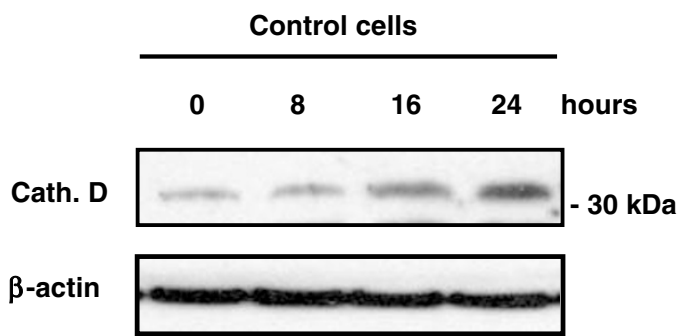

Figure 4 Doxorubicin treatment induces a caspase-independent activation of cathepsin D. (a) Doxorubicin-induced increase of cathepsin D enzymatic activity in control fibroblasts isolated from healthy sheep. Cells were incubated for the indicated times in $1 \% \mathrm{FCS}$ and $1 \mu \mathrm{M}$ doxorubicin in the presence or absence of $25 \mu \mathrm{M}$ zVAD-fmk (added to the cell culture medium $2 \mathrm{~h}$ prior to addition of doxorubicin). Cells were harvested and cathepsin $D$ enzymatic activity was determined using AMCA-Hb as a substrate. Data are means \pm S.E. of three independent experiments. (b) Western blot analysis of cathepsin $\mathrm{D}$ active heavy chain form $(31 \mathrm{kDa})$ before and after treatment with $1 \mu \mathrm{M}$ doxorubicin. Cell lysates were prepared at the indicated time points from control fibroblasts. An anti- $\beta$-actin was used as a control for protein loading. Results are representative of three independent experiments

of doxorubicin was abolished (Figure $2 b$ ). This suggested that cathepsin $\mathrm{D}$ activation does not mediate doxorubicin-induced apoptosis.

\section{Doxorubicin-induced ceramide generation in cathepsin D-deficient cells}

Since anthracycline-mediated apoptosis has been described to be accompanied by the production of the sphingolipidic proapoptotic mediator ceramide, ${ }^{36,37}$ we next investigated the effect of doxorubicin on intracellular ceramide levels measured in drug-treated ovine cells. Figure 5 shows that doxorubicin induced a rapid, transient increase in ceramide levels (peak within the first $5 \mathrm{~min}$ of incubation). Later, the amount of ceramide increased again. After $20 \mathrm{~h}$ of treatment, that is, after the activation of executioner caspases, it was nearly doubled in both control and CONCL cells as compared to the initial value (Figure $3 b$ ). This result suggested that doxorubicin induced an accumulation of ceramide independently of cathepsin D activity.

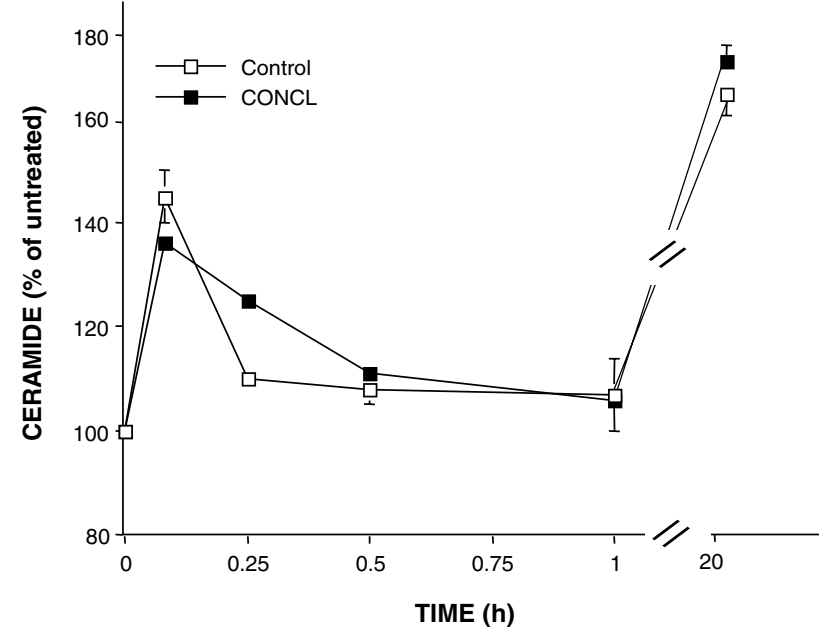

Figure 5 Effect of the deficiency in cathepsin $D$ on doxorubicin-induced ceramide generation. SV40-transformed cells were incubated in 1\% FCS with $1 \mu \mathrm{M}$ doxorubicin for the indicated times. Cells were then harvested and ceramide was quantified using the diacylglycerol kinase method

\section{Effect of cytotoxic agents on cathepsin D-deficient cells}

Since different cytotoxic agents, including naphthazarin ${ }^{25,38}$ and sphingosine ${ }^{39}$ have been reported to induce apoptosis via activating cathepsin $D$, we compared the effects of various apoptotic inducers in cathepsin D-deficient cells and control cells. Figure 6 shows that whatever the stress agent tested, cathepsin $D$ deficiency did not alter cell death induction in either control or CONCL fibroblasts.

\section{Effect of pepstatin A on drug-induced cell death in control and acid ceramidase-deficient cells}

To further evaluate the role of lysosomal cathepsin D in apoptosis, we preincubated human SV40-transformed skin fibroblasts and Epstein-Barr virus-transformed lymphoid cell lines with pepstatin $A$, an inhibitor of lysosomal aspartic proteinases. Pretreatment of human cells with $100 \mu \mathrm{M}$ pepstatin A resulted in strong inhibition of cathepsin D activity (85 and $75 \%$ in fibroblasts and lymphoblasts, respectively; data not shown). In spite of this inhibition, cell death induced by doxorubicin or TNF- $\alpha$ in fibroblasts (Figure 7a) or by doxorubicin or anti-CD95 in lymphoblasts (Figure 7b) was not prevented by pepstatin $A$. These results were also observed in ovine control cells treated with doxorubicin in the presence of pepstatin A (data not shown).

Since cathepsin $D$ has been reported as a target of endosomal ceramide, ${ }^{40}$ we then analyzed the relation between cathepsin $D$ activity and ceramide. For this purpose, we investigated the effect of pepstatin $A$ in cells derived from patients affected with Farber disease, having a genetic defect of acid ceramidase activity leading to lysosomal accumulation of ceramide. As shown in Figure 7, the cytotoxic effect of doxorubicin or TNF- $\alpha$ in Farber disease fibroblasts (Figure 7a), as well as doxorubicin or CD95 ligation in Farber disease lymphoblasts (Figure $7 \mathrm{~b}$ ), was similar to that observed in control cells or in genetically corrected Farber disease cells 


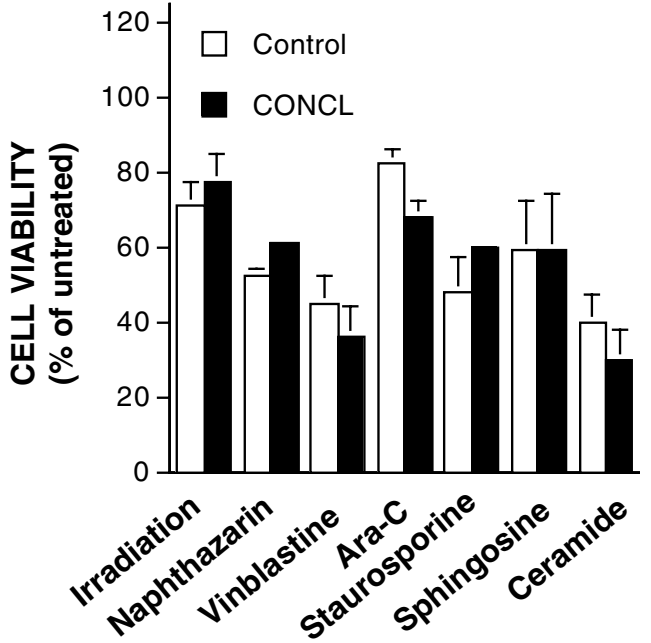

Figure 6 The deficiency in cathepsin $D$ activity does not protect cells against toxicity of different cytotoxic agents. SV40-transformed control and CONCL fibroblasts were incubated in $10 \%$ FCS for $48 \mathrm{~h}$ after irradiation at $10 \mathrm{~Gy}$, in $1 \%$ FCS for $5 \mathrm{~h}$ with $0.5 \mu \mathrm{M}$ naphthazarin, under serum-free conditions for $24 \mathrm{~h}$ with $10 \mu \mathrm{M}$ vinblastine or $100 \mu \mathrm{M}$ ara-C or in $1 \%$ FCS for $24 \mathrm{~h}$ with $100 \mathrm{nM}$ staurosporine, $15 \mu \mathrm{M}$ sphingosine, $20 \mu \mathrm{M}$ ceramide. Cell viability was assessed by MTT assay, by comparing untreated and treated cells. Results are means \pm S.E. of three independent experiments which overexpress acid ceramidase, in agreement with previous data. ${ }^{41}$ Of interest was the finding that the cytotoxicity was not prevented by pepstatin $\mathrm{A}$, consistent with the idea that cathepsin $D$ is not activated by endolysosomal ceramide. These results were confirmed by the observation that cathepsin D activity was not enhanced in extracts of Farber disease cells, compared to the activity measured in extracts of normal cells or Farber disease cells that were corrected by retroviral gene transfer (data not shown).

\section{Effects of cytotoxic agents in I-cell-disease fibroblasts}

Several reports suggest that lysosomes are key effectors of cell death pathways. ${ }^{14,42,43}$ To assess the role of lysosomal enzymes in apoptosis, we used fibroblasts from patients with I-cell disease (or mucolipidosis II), an inborn human disorder. These cells exhibit an impaired function of lysosomal enzymes due to a deficiency of $\mathrm{N}$-acetylglucosamine-1phosphotransferase, an enzyme involved in phosphorylation of mannose residues of the newly synthesized hydrolases, allowing their targeting to lysosomes. ${ }^{44}$ As illustrated, I-celldisease fibroblasts had severely reduced activities of $\beta$ galactosidase (Figure 8d) and $\beta$-hexosaminidase (Figure 8e),

FIBROBLASTS

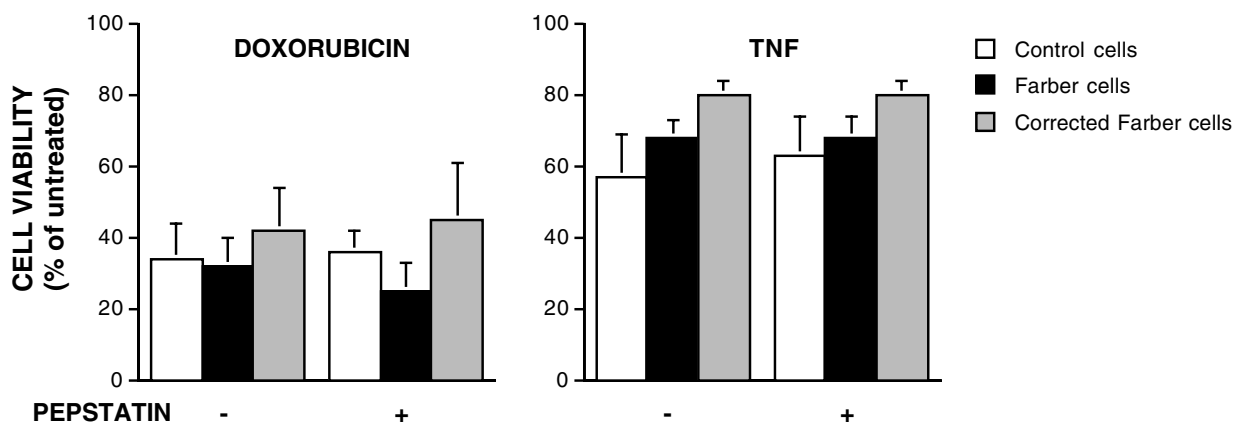

b

LYMPHOBLASTS
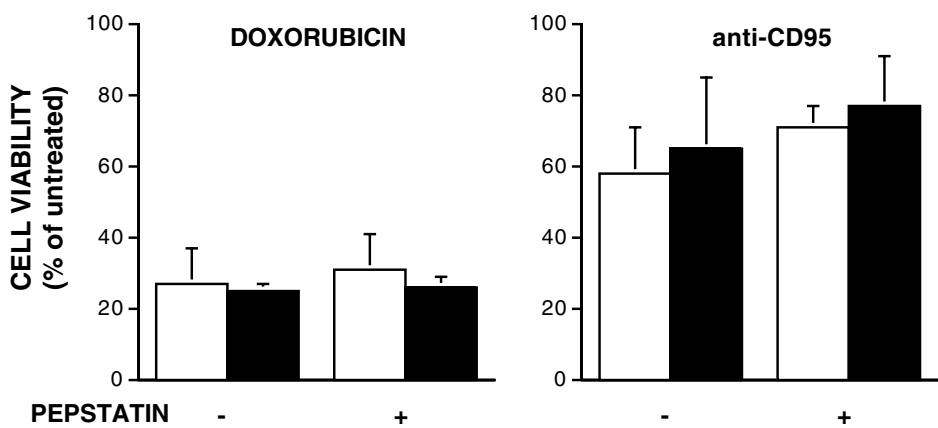

$\square$ Control cells

Farber cells

Figure 7 Pepstatin A does not prevent stress-induced cell death in human fibroblasts or lymphoblasts. (a) SV40-transformed skin fibroblasts (Control, Farber disease or Corrected Farber cells) were preincubated or not for $1 \mathrm{~h}$ with $100 \mu \mathrm{M}$ pepstatin $\mathrm{A}$ and then incubated for $48 \mathrm{~h}$ in $1 \% \mathrm{FCS}$ with $1 \mu \mathrm{M}$ doxorubicin or $50 \mathrm{ng} / \mathrm{ml}$ TNF- $\alpha$. (b) EBV-transformed lymphoid cell lines (Control or Farber disease cells) were preincubated or not for $1 \mathrm{~h}$ with $100 \mu \mathrm{M}$ pepstatin A and then incubated for $48 \mathrm{~h}$ in $1 \% \mathrm{FCS}$ with $1 \mu \mathrm{M}$ doxorubicin or $50 \mathrm{ng} / \mathrm{ml}$ anti-CD95. Cell viability was assessed by MTT assay, by comparing untreated and treated cells. Results are means \pm S.E. of $4-10$ independent experiments 
a

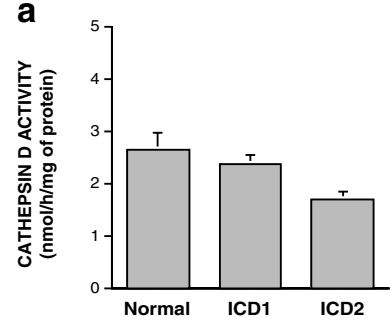

C
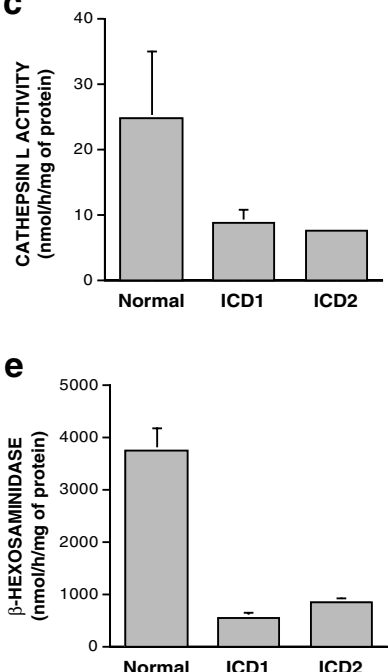

b

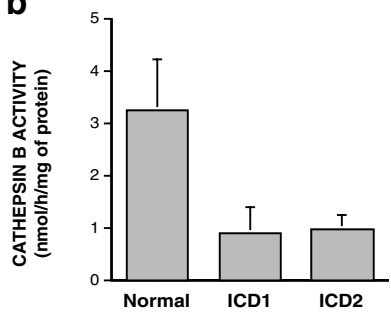

d

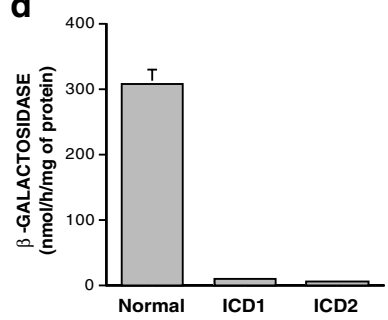

$\mathbf{f}$

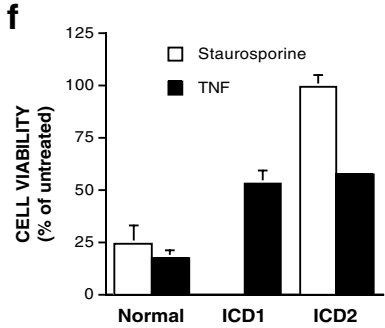

Figure 8 I-cell disease fibroblasts are resistant to killing by TNF and staurosporine. Activities of cathepsin D (a), cathepsin B (b), cathepsin L (c), $\beta$-galactosidase (d), and $\beta$-hexosaminidase (e) were determined in human SV40-transformed skin fibroblasts derived from normal individuals (normal) and two patients affected with Icell disease (ICD1 and ICD2). Results are means \pm S.E. of three independent determinations. (f) Normal or I-cell-disease SV40-transformed fibroblasts were incubated for $24 \mathrm{~h}$ in $1 \%$ FCS in the presence of $100 \mathrm{nM}$ staurosporine or $50 \mathrm{ng} / \mathrm{ml}$ TNF- $\alpha$ and $50 \mu \mathrm{g} / \mathrm{ml}$ cycloheximide. Cell viability was assessed by MTT assay, by comparing untreated and treated cells. Results are means \pm S.E. of three to five independent determinations (all in triplicate). Cell viability in ICD1 and ICD2 cells was significantly higher than in control cells $(P<0.0001)$

as compared to normal fibroblasts, but displayed only a slight decrease in the activity of cathepsin $D$ (Figure 8a). In addition, activities of cathepsins $B$ and $L$ were decreased in these mutant cells (Figure $8 b$ and $c$ ).

When the response of I-cell disease fibroblasts to $100 \mathrm{nM}$ staurosporine or $15 \mu \mathrm{M}$ sphingosine was compared to that of normal cells, almost no DNA fragmentation was observed in the former (data not shown). In addition, unlike the control cells, transformed I-cell disease fibroblasts were resistant to TNF- $\alpha$ (Figure $8 \mathrm{f}$ ). It is of interest to note that the resistance of mutant cells was not correlated with a decrease in the activity of cathepsin D (Figure 8a), suggesting that some lysosomal hydrolases, other than cathepsin $\mathrm{D}$, are implicated in apoptotic cell death.

\section{Effect of cathepsin inhibitors on TNF-induced cell death}

To further investigate the mechanisms for resistance of I-cell disease fibroblasts and to assess the possible contribution of cathepsins in apoptosis, several cysteine protease inhibitors were tested for their ability to protect control fibroblasts from TNF-induced apoptosis. Whereas leupeptin, E64 and the purported specific cathepsin B inhibitor [L-3-trans-propylcarbamoyl)oxirane-2-carbonyl]-L-isoleucyl-L-proline methyl ester (CA-074 Me), inhibited both cathepsin $B$ and $L$ activities (Figure $9 a$ and $b$ ), they all failed to protect normal fibroblasts from TNF-induced cell death (Figure 9c). However, $\mathrm{N}$-acetyl-
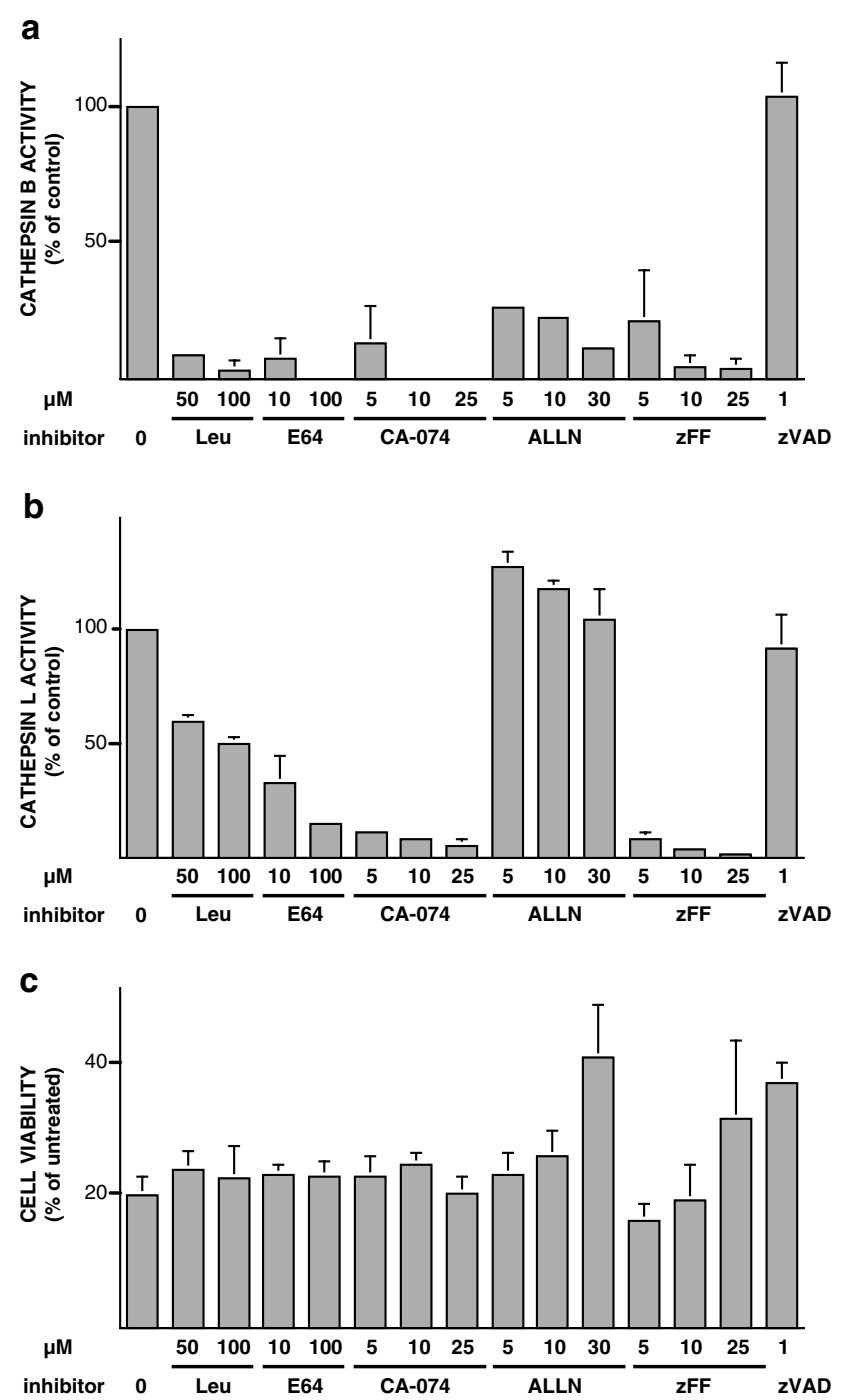

Figure 9 Effect of cathepsin inhibitors on sensitivity of fibroblasts to TNF. Human SV40-transformed skin fibroblasts derived from a normal individual were treated for $1 \mathrm{~h}$ with the indicated inhibitor. Cell lysates were then prepared and activities of cathepsin B (a) and cathepsin L (b) were determined. Results are means \pm S.E. of three independent determinations. (c) Fibroblasts were preincubated for $1 \mathrm{~h}$ with the indicated inhibitor and then treated for $24 \mathrm{~h}$ in $1 \%$ FCS in the presence of $50 \mathrm{ng} / \mathrm{ml} \mathrm{TNF}-\alpha$ and $50 \mu \mathrm{g} / \mathrm{ml}$ cycloheximide. Cell viability was assessed by MTT assay, by comparing cells treated with TNF to cells incubated in the absence of the cytokine. Results are means \pm S.E. of three to five independent determinations (all in triplicate). Cell viability in $30 \mu \mathrm{M} \mathrm{ALLN}$, $25 \mu \mathrm{M}$ zFF-fmk and $1 \mu \mathrm{M}$ zVAD-fmk-treated cells was significantly higher than in cells incubated in the absence of these inhibitors $(P<0.0001, P<0.05$ and $P$ $<0.0001$, respectively). Abbreviations: Leu, leupeptin; zFF, zFF-fmk; zVAD, zVAD-fmk. Some bars or standard errors are too small to be seen. 
leu-leu-norleucinal (ALLN), a presumed calpain inhibitor, and benzyloxycarbonyl-phe-phe-fluoromethylketone (zFF-fmk), a cathepsin L inhibitor, slightly, but significantly, conferred protection against TNF-induced cell death. These two compounds strongly inhibited cathepsin B activity (Figure 9a), while cathepsin L was inhibited only by zFF-fmk (Figure 9b). Of note, zVAD-fmk at a very low concentration, which did not alter cathepsin activity, still protected fibroblasts (Figure 9c). These observations suggest that cathepsins B and/or $L$ (and possibly other proteases) may participate to some extent in TNF signaling of cell death.

\section{Discussion}

\section{Cathepsin D in cell death}

For many years, lysosomes have been considered as 'suicide bags' that would release unspecific digestive enzymes after uncontrolled cell damage. Recent studies on cultured cells suggest, however, that some lysosomal proteases, in particular cathepsins $D$ and $B$, may act as mediators of programmed cell death (for reviews see Leist and Jaattela ${ }^{13}$, Salvesen ${ }^{15}$, Bursch ${ }^{43}$ and Kidd et al. ${ }^{45}$ ).

Studies on animals lacking either cathepsin D activity or protein have provided further insight into the functions of cathepsin D. In contrast to in vitro studies, findings in these animal models did not support a role for cathepsin D in apoptosis. Indeed, homozygous cathepsin D-deficient mutant mice exhibit ileal atrophy and loss of lymphoid cells, leading to death in the fourth week of life. ${ }^{46}$ These mice also exhibit increased apoptosis in the thymus, ${ }^{46}$ thalamus ${ }^{47}$ and retina. ${ }^{48}$ Similar neuronal storage and death have been found in the cathepsin D-deficient sheep. ${ }^{12}$ An increased photoreceptor cell death has also been noticed in a transgenic mouse model expressing an enzymatically inactive cathepsin D. ${ }^{49}$ These observations strongly suggest that cathepsin $D$ is essential for the proteolysis of proteins regulating cell growth and tissue homeostasis.

Further studies on animals have shown that in 3Y1-Ad12, tumor xenografts expression of either catalytically active or inactive cathepsin $D$ at a high level can stimulate both cancer cell proliferation and angiogenesis, indicating a proliferationrelated function of cathepsin D protein in these cells. ${ }^{50}$ In addition, transfection of embryonic rat tumorigenic cells with an expression vector encoding human cathepsin D was reported to increase their metastatic potential in nude mice. ${ }^{51}$ Conversely, downregulation of cathepsin $\mathrm{D}$ expression by antisense gene transfer was described to inhibit tumor growth and experimental lung metastasis of human breast cancer cells. ${ }^{52}$

In general accordance with these studies, the present work demonstrates that stress-induced cell death is not affected in cells isolated from cathepsin D-deficient sheep or in human cells treated with pepstatin A, a well-known inhibitor of cathepsin D. Specifically, we show that cathepsin D is implicated neither in cell death induced by death receptors (TNF or CD95) nor after addition of other classes of apoptotic inducers (doxorubicin, vinblastine, ara-C, gamma radiation, staurosporine, sphingosine, ceramide or naphthazarin). These findings are in good agreement with recent observa- tions that lysosomal cathepsin D is not positively connected with cell death, ${ }^{22,28,30}$ but conflict with other reports mentioning that inhibition of cathepsin D suppresses cell death ${ }^{17-19,24}$ and most particularly with data obtained on fibroblasts from cathepsin D-deficient mice. ${ }^{17,18}$

In both affected animal models of cathepsin D deficiency (i.e., knockout mice and CONCL sheep), the catalytic activity of the aspartic protease is abrogated. ${ }^{12,46}$ However, in contrast to the gene disruption model, CONCL cells still contain the cathepsin D protein. ${ }^{12,53}$ Our data on CONCL cells therefore indicate that the enzyme activity of cathepsin $D$ is not required for efficient induction of cell death. This conclusion, however, does not rule out the possibility that the catalytically inactive cathepsin D might be implicated in apoptosis. This hypothesis would not be inconsistent with the observation that a mutated human cathepsin D carrying the corresponding substitution found in the affected sheep still promoted cancer cell proliferation, behaving as the wild-type cathepsin D. ${ }^{54}$

Regarding the connection between caspases and lysosomal proteases, of interest is the finding that doxorubicininduced control ovine cell death was accompanied by an increase in cathepsin $\mathrm{D}$ activity and processing, in agreement with several reports. ${ }^{17,19,27}$ This increase, however, which peaked after caspase activation, was not prevented in cells preincubated with zVAD-fmk, whereas the cytotoxic effect of the drug was abolished. Altogether, our data support the idea that, on the one hand, caspases are not substrates of cathepsin D (and vice versa), consistent with the observation that purified lysosomal cathepsins or an extract of mouse lysosomes did not directly activate either recombinant caspase zymogens or caspase zymogens present in human neuronal cytosolic extract. ${ }^{55}$ On the other hand, our study demonstrates that cathepsin $\mathrm{D}$ activation does not mediate doxorubicin-induced apoptosis. This observation raises an important, still unsolved question such as the function of cathepsin D in cell death. Is it activated only during the terminal stages, causing membrane lysis and irreversible loss of viability? Or, conversely, has it got some mitogenic functions as noticed in cancer cells. ${ }^{50,52}$ Clearly, further investigations will be required to answer this question. Seemingly conflicting reports on the role of cathepsin D in apoptosis refer to different systems. Therefore, it is possible that this enzyme participates in one or more pathways within a ramified system of reactions leading to cell death.

\section{Cathepsin D and ceramide}

Cathepsin $D$ has been reported to be regulated by the sphingolipids, sphingosine ${ }^{39}$ and ceramide, derived from the hydrolysis of sphingomyelin by acid sphingomyelinase. ${ }^{40}$ In acidic compartments, the levels of ceramide and sphingosine are directly controlled by the activity of acid ceramidase, which deacylates ceramide to yield sphingosine.

The present study demonstrates that doxorubicin-induced ceramide generation occurs before cathepsin D activation. These findings are in line with reports showing that lysosomal proteases can be regulated by sphingolipids. ${ }^{39,40,56}$ The interaction between ceramide and cathepsin $D$ has been proposed to result in an autocatalytic proteolysis of the $52 \mathrm{kDa}$ 
pre-procathepsin $D$ to form the enzymatically active isoforms of the protease. ${ }^{40}$ In contrast to these observations, a recent report demonstrates that the transport and processing of cathepsin D are inhibited during ceramide-induced apoptosis in human colon adenocarcinoma cells. ${ }^{56}$

It is possible that, in fibroblasts used in this study, the activity of cathepsin D is modulated by ceramide. However, we show that ceramide and sphingosine generated in endolysosomal compartments affect neither the maturation of cathepsin D nor its enzymatic activity. Indeed, we observed that ceramide accumulation in human cells deficient in acid ceramidase does not lead to an increase in cathepsin D activity in cell extracts (unpublished observations). In addition, modulating the levels of ceramide and sphingosine in the endosomal/lysosomal compartment by acting on acid ceramidase levels did not alter apoptosis (Figure 7 and Ségui et $\left.a .^{41}\right)$, and this process was unaffected by pepstatin $A$, again suggesting that sphingolipid activation of cathepsin $D$ plays little role in cell death induction.

\section{Lysosomal enzymes in cell death}

Whereas cathepsin D appears not to play an instrumental role in stress-induced cell death, the involvement of some other lysosomal enzymes cannot be excluded. Indeed, we show that cells from patients with I-cell disease are resistant to apoptosis induction by cytotoxic agents, in agreement with a recent report. ${ }^{57}$ Interestingly, the resistance of these mutant cells was not correlated with a decreased activity of cathepsin $D$, further substantiating our previous conclusions.

Regarding cell death, two lysosomal cysteine proteases, cathepsins $B$ and $L$, could be candidates to play a critical role. Indeed, cathepsin B has been reported to mediate TNF- $\alpha$ induced apoptosis. ${ }^{58}$ Among other cysteine cathepsins, cathepsin B itself is inhibited by the frequently used but obviously nonspecific caspase inhibitor zVAD-fmk. ${ }^{59}$ In addition, cathepsin $L$ has recently been described to be activated during the apoptotic program in newts. ${ }^{60}$ In accordance with these observations, fibroblasts from patients with I-cell disease, which exhibit reduced cathepsin $B$ and $L$ activities, partially resisted TNF-induced cell death. Also, pharmacological inhibition of these cathepsins partially protected control fibroblasts against TNF. However, none of the inhibitors employed proved to be strictly specific for a particular protease. Although these findings point to a role for lysosomal cysteine protease(s) in apoptosis, identification of the implicated cathepsin(s) still requires further investigation.

In summary, the present study demonstrates that cathepsin D deficiency does not protect fibroblasts against caspase activation and cell death induced by doxorubicin and a variety of other cytotoxic agents. In the same way, the cathepsin D inhibitor, pepstatin A, did not prevent stress-induced cell death in human fibroblasts or lymphoblasts. However, a normal lysosomal function seems to be required for efficient cell death, as indicated by the finding that fibroblasts from patients with mucolipidosis II were resistant to apoptosis. While cathepsin D appears not to be instrumental in anticancer drug-induced apoptosis, these observations place lysosomes as an important component of the cell death machinery.

\section{Materials and Methods}

\section{Reagents}

Pepstatin, doxorubicin, staurosporine, 5,8-dihydroxy-1,4-naphthoquinone, 4',6-diamidino-2-phenylindole (DAPI), 3-(4,5-dimethylthiazol-2-yl)-2,5-diphenyltetrazolium bromide (MTT), ALLN and E64 were supplied from Sigma (Lisle d'Abeau, France). Sphingosine and cell-permeant $\mathrm{C}_{2}$-ceramide were from BioMol-Tebu (Le Perray en Yvelines, France). Human recombinant TNF- $\alpha$ was purchased from Peprotech-Tebu (Le Perray en Yvelines, France). Anti-CD95 was from Beckman-Coulter (Marseille, France).

1- $\beta$-D-arabinofuranosylcytosine (ara-C) was obtained from Upjohn (Paris, France) and vinblastine from $\mathrm{NCl}$ drug repository. zVAD-fmk, z-Phe-Arg-7amido-4-methylcoumarin (zFR-AMC), and Ac-Asp-Glu-Val-Asp-7-amido-4methylcoumarin (Ac-DEVD-AMC) were from Bachem (Voisins-Le-Bretonneux, France), and 6-[(7-amino-4-methylcoumarin-3-acetyl) amino]-hexanoic acid succinimide from Molecular Probes (Leiden, The Netherlands). CA-074 Me, z-arg-arg-7-amido-4-methylcoumarin (zRR-AMC) and zFF-fmk were obtained from Calbiochem. RPMI 1640 Glutamax, DMEM, trypsinEDTA, penicillin and streptomycin were from Gibco BRL (Cergy-Pontoise, France); FCS was from BioMedia (Boussens, France).

\section{Cell culture}

Fibroblasts from wild-type and CONCL sheeps were transfected or not with a plasmid encoding SV40 large T antigen. ${ }^{61}$.DNA sequencing indicated that SV40-transformed CONCL fibroblasts still exhibited the cathepsin D gene defect. Human SV40-transformed skin fibroblasts were derived from normal individuals or from a patient affected with Farber disease, who died at 3 days of age (line Moh). Fibroblasts were also obtained from normal individuals or two patients affected with I-cell disease. These cells were grown in a humidified $5 \% \mathrm{CO}_{2}$ atmosphere at $37^{\circ} \mathrm{C}$ in DMEM medium containing Glutamax (2 mM), penicillin (100 U/ml), streptomycin $(100 \mu \mathrm{g} / \mathrm{ml})$ and heat-inactivated FCS $(10 \%) .{ }^{61}$ Human Epstein-Barr virus (EBV)-transformed lymphoid cell lines were derived from control subjects or from patients affected with Farber disease, and were grown in RPMI 1640 medium containing 10\% FCS.

\section{Cytotoxicity and DNA fragmentation assay}

Cell viability was evaluated by using the tetrazolium-based MTT assay. ${ }^{62}$ After treatment with or without a drug, cells were washed with PBS, lysed for $20 \mathrm{~min}$ at $4^{\circ} \mathrm{C}$ in $0.5 \mathrm{ml}$ lysis buffer $(0.5 \%$ Triton X-100 v/v, $20 \mathrm{mM}$ EDTA and $5 \mathrm{mM}$ Tris- $\mathrm{HCl}, \mathrm{pH} 8.0$ ) and then centrifuged for $15 \mathrm{~min}$ at $51000 \times g$, in order to separate the DNA fragments from the chromatin pellet. The DNA content of pellet (resuspended in $0.5 \mathrm{ml}$ of $1 \mathrm{mM}$ EDTA in $10 \mathrm{mM}$ Tris- $\mathrm{HCl}, \mathrm{pH} 8.0$ buffer) and supernatant was determined by the fluorometric DAPI procedure. ${ }^{37}$

\section{Fluorogenic DEVD cleavage enzyme assay}

After incubation with doxorubicin, cells were sedimented and washed with PBS. Cell pellets were homogenized in $10 \mathrm{mM}$ HEPES (pH 7.4), $42 \mathrm{mM}$ $\mathrm{KCl}, 5 \mathrm{mM} \mathrm{MgCl} 2,0.5 \%$ CHAPS, $1 \mathrm{mM}$ dithiothreitol, $1 \mathrm{mM}$ PMSF and $2 \mu \mathrm{g} / \mathrm{ml}$ leupeptin. Reaction mixtures contained $100 \mu \mathrm{l}$ of cell lysates and $100 \mu \mathrm{l}$ of $40 \mu \mathrm{M}$ Ac-DEVD-AMC. After $30 \mathrm{~min}$ incubation at room temperature, the amount of the released fluorescent product, aminomethylcoumarin, was determined at 351 and $430 \mathrm{~nm}$ for the excitation and emission wavelengths, respectively. 


\section{Western blot analyses}

Equal amounts of proteins were separated on $12.5 \%$ SDS-polyacrylamide gel and transferred to a nitrocellulose membrane. Cathepsin D was detected by using a rabbit polyclonal antiserum (Oncogene, France Biochem, Meudon, France); p53 was detected with a mouse polyclonal antiserum (Oncogene). Goat anti-rabbit and anti-mouse secondary antibodies were from Ozyme (Montigny Le Bretonneux, France). An anti- $\beta$-actin (Sigma) was used as a control for protein loading.

\section{Lipid extraction and ceramide quantification}

Cell pellets were suspended in $0.5 \mathrm{ml}$ distilled water and sonicated for $10 \mathrm{~s}$. After an aliquot was taken for protein determination, the lipids were extracted. ${ }^{63}$ Ceramide levels were quantitated in the lipid extracts essentially as described, ${ }^{64}$ using $E$. coli diacylglycerol kinase (kindly provided by Drs Perry and Hannun, Charleston, SC) and [ $\gamma^{32}$ P]ATP (Perkin-Elmer, Courtaboeuf, France). Radioactive ceramide-1-phosphate was isolated by TLC, using chloroform/acetone/methanol/acetic acid/ water $(50: 20: 15: 10: 5$, by vol.) as the developing solvent, and counted by liquid scintillation.

\section{Determination of cathepsin activity}

Cathepsin $D$ activity was determined by measuring hydrolysis of AMCA$\mathrm{Hb}$, a hemoglobin derivative covalently modified with 6-[(7-amino-4methylcoumarin-3-acetyl) amino] hexanoic acid succinimide, at $\mathrm{pH}$ 3.7. in the presence and absence of $5 \mu \mathrm{M}$ pepstatin A. Cell pellets were homogenized in $250 \mu \mathrm{l}$ distilled water. Reaction mixtures contained $100 \mu \mathrm{l}$ of cell suspension and $100 \mu \mathrm{l}$ of substrate preparation ( $25 \mathrm{mM}$ acetate/ $25 \mathrm{mM}$ formiate/ $\mathrm{NaOH}$ buffer (pH 3.7), $50 \mu \mathrm{M}$ leupeptin and $300 \mu \mathrm{g} / \mathrm{ml}$ AMCA- $\mathrm{Hb}$ ). After $3 \mathrm{~h}$ incubation at $37^{\circ} \mathrm{C}$, the reaction was stopped on ice by adding $50 \mu \mathrm{l}$ of $50 \%$ trichloroacetic acid. After centrifugation for $5 \mathrm{~min}$ at $15000 \times g, 100 \mu \mathrm{l}$ of supernatant as neutralized with $900 \mu \mathrm{l}$ of Tris- $\mathrm{HCl}$ $0.5 \mathrm{M} \mathrm{pH} 9$ and the amount of the released fluorescent product aminomethylcoumarin was determined by fluorometry at 358 and $448 \mathrm{~nm}$ for the excitation and emission wavelengths, respectively.

Cathepsin B activity was determined by using zRR-AMC, and cathepsin $\mathrm{L}$ activity using zFR-AMC, at pH 5 (100 mM sodium acetate buffer), as previously described. ${ }^{65}$ After 30 min incubation at $30^{\circ} \mathrm{C}$ (for cathepsin $\mathrm{B}$ ) or $37^{\circ} \mathrm{C}$ (for cathepsin $\mathrm{L}$ ), the reaction was stopped by adding of $100 \mathrm{mM}$ sodium chloroacetate, and the amount of the released fluorescent product, aminomethylcoumarin, was determined by fluorometry. Since zFR-AMC is hydrolyzed both by cathepsin $B$ and $L$, enzyme activity was measured in the absence or presence of $5 \mu \mathrm{M}$ CA-074 Me, and cathepsin L activity was determined as the CA-074 Me-resistant activity.

\section{Other lysosomal enzyme assays}

$\beta$-Hexosaminidase and $\beta$-galactosidase activities were determined using $0.5 \mathrm{mg} / \mathrm{ml}$. of the appropriate 4-methylumbelliferyl substrate at $\mathrm{pH} 4.5$ and 3.7 , respectively, in the presence of $0.1 \%$ Triton $X-100 .{ }^{66}$ Protein concentration was measured with the Bio-Rad dye reagent using bovine serum albumin as a standard.

\section{Statistical analyses}

Data are presented as mean \pm S.E.M. Student's $t$-test was used for statistical analysis.

\section{Acknowledgements}

We thank Drs O Cuvillier and R Salvayre for discussions, S Carpentier, V Garcia and JC Thiers for technical assistance, and Dr HG Löffler for preparing AMCA-Hb. This work was supported by grants from INSERM, Université Paul Sabatier, and the Association Vaincre les Maladies Lysosomales. CT is a recipient of an MESR fellowship.

\section{References}

1. Rawlings ND, O'Brien E and Barrett AJ (2002) MEROPS: the protease database. Nucleic Acids Res. 30: 343-346

2. Erickson AH (1989) Biosynthesis of lysosomal endopeptidases. J. Cell Biochem. 40: 31-41

3. Reid WA, Valler MJ and Kay J (1986) Immunolocalization of cathepsin D in normal and neoplastic human tissues. J. Clin. Pathol. 39: 1323-1330

4. Barrett AJ (1977) Cathepsin D and other carboxyl proteinases. In Proteinases in Mammalian Cells and Tissues, Barrett AJ (ed) (Amsterdam: Elsevier/NorthHolland Biochemical Press), pp. 209-248

5. Tandon AK, Clark GM, Chamness GC, Chirgwin JM and McGuire WL (1990) Cathepsin D and prognosis in breast cancer. N. Engl. J. Med. 322: 297-302

6. Gelb BD, Shi GP, Chapman HA and Desnick RJ (1996) Pycnodysostosis, a lysosomal disease caused by cathepsin K deficiency. Science 273: 1236-1238

7. Itoh K, Miharu N, Ohama K, Mizoguchi N, Sakura N and Sakuraba H (1997) Fetal diagnosis of galactosialidosis (protective protein/cathepsin A deficiency). Clin. Chim. Acta 266: 75-82

8. Saftig P, Hunziker E, Wehmeyer O, Jones S, Boyde A, Rommerskirch W, Moritz JD, Schu P and von Figura K (1998) Impaired osteoclastic bone resorption leads to osteopetrosis in cathepsin-K-deficient mice. Proc. Natl. Acad. Sci. USA 95: 13453-13458

9. Hart TC, Hart PS, Bowden DW, Michalec MD, Callison SA, Walker SJ, Zhang Y and Firatli E (1999) Mutations of the cathepsin C gene are responsible for Papillon-Lefevre syndrome. J. Med. Genet. 36: 881-887

10. Toomes C, James J, Wood AJ, Wu CL, McCormick D, Lench N, Hewitt C, Moynihan L, Roberts E, Woods CG, Markham A, Wong M, Widmer R, Ghaffar KA, Pemberton M, Hussein IR, Temtamy SA, Davies R, Read AP, Sloan P, Dixon MJ and Thakker NS (1999) Loss-of-function mutations in the cathepsin C gene result in periodontal disease and palmoplantar keratosis. Nat. Genet. 23 : $421-424$

11. Koike M, Nakanishi H, Saftig P, Ezaki J, Isahara K, Ohsawa $Y$, SchulzSchaeffer W, Watanabe T, Waguri S, Kametaka S, Shibata M, Yamamoto K, Kominami E, Peters C, von Figura K and Uchiyama Y (2000) Cathepsin D deficiency induces lysosomal storage with ceroid lipofuscin in mouse CNS neurons. J. Neurosci. Res. 20: 6898-6906

12. Tyynela J, Sohar I, Sleat DE, Gin RM, Donnelly RJ, Baumann M, Haltia M and Lobel $P(2000)$ A mutation in the ovine cathepsin $D$ gene causes a congenital lysosomal storage disease with profound neurodegeneration. EMBO J. 19: 2786-2792

13. Leist $M$ and Jaattela $M$ (2001) Triggering of apoptosis by cathepsins. Cell Death Differ. 8: 324-326

14. Johnson DE (2000) Noncaspase proteases in apoptosis. Leukemia 14: 16951703

15. Salvesen GS (2001) A lysosomal protease enters the death scene. J. Clin. Invest. 107: 21-22

16. Czaja MJ (2001) TNF toxicity-death from caspase or cathepsin, that is the question. Hepatology 34: 844-846

17. Wu GS, Saftig P, Peters $C$ and El-Deiry WS (1998) Potential role for cathepsin D in p53-dependent tumor suppression and chemosensitivity. Oncogene 16: $2177-2183$

18. Neuzil J, Zhao M, Ostermann G, Sticha M, Gellert N, Weber C, Eaton JW and Brunk UT (2002) Alpha-tocopheryl succinate, an agent with in vivo anti-tumour activity, induces apoptosis by causing lysosomal instability. Biochem. J. 362: 709-715

19. Deiss LP, Galinka H, Berissi H, Cohen $O$ and Kimchi A (1996) Cathepsin D protease mediates programmed cell death induced by interferon-gamma, Fas/ APO-1 and TNF-alpha. EMBO J. 15: 3861-3870 
20. Shibata M, Kanamori S, Isahara K, Ohsawa $Y$, Konishi A, Kametaka S, Watanabe T, Ebisu S, Ishido K, Kominami E and Uchiyama Y (1998) Participation of cathepsins $B$ and $D$ in apoptosis of $P C 12$ cells following serum deprivation. Biochem. Biophys. Res. Commun. 251: 199-203

21. Roberg K, Kagedal K and Ollinger K (2002) Microinjection of cathepsin D induces caspase-dependent apoptosis in fibroblasts. Am. J. Pathol. 161: 89-96

22. Demoz M, Castino R, Cesaro P, Baccino FM, Bonelli G and Isidoro C (2002) Endosomal-lysosomal proteolysis mediates death signalling by TNFalpha, not by etoposide, in L929 fibrosarcoma cells: evidence for an active role of cathepsin D. Biol. Chem. 383: 1237-1248

23. Roberts LR, Adjei PN and Gores GJ (1999) Cathepsins as effector proteases in hepatocyte apoptosis. Cell Biochem. Biophys. 30: 71-88

24. Roberg K, Johansson U and Ollinger K (1999) Lysosomal release of cathepsin $D$ precedes relocation of cytochrome $c$ and loss of mitochondrial transmembrane potential during apoptosis induced by oxidative stress. Free Radic. Biol. Med. 27: 1228-1237

25. Kagedal K, Johansson U and Ollinger K (2001) The lysosomal protease cathepsin $\mathrm{D}$ mediates apoptosis induced by oxidative stress. FASEB J. 15: 1592-1594

26. Zang Y, Beard RL, Chandraratna RA and Kang JX (2001) Evidence of a lysosomal pathway for apoptosis induced by the synthetic retinoid CD437 in human leukemia HL-60 cells. Cell Death Differ. 8: 477-485

27. Takuma K, Kiriu M, Mori K, Lee E, Enomoto R, Baba A and Matsuda T (2003) Roles of cathepsins in reperfusion-induced apoptosis in cultured astrocytes. Neurochem. Int. 42: 153-159

28. Reiners Jr JJ, Caruso JA, Mathieu P, Chelladurai B, Yin XM and Kessel D (2002) Release of cytochrome $c$ and activation of pro-caspase-9 following lysosomal photodamage involves bid cleavage. Cell Death Differ. 9: 934-944

29. Isahara K, Ohsawa $Y$, Kanamori S, Shibata M, Waguri S, Sato N, Gotow T, Watanabe T, Momoi T, Urase K, Kominami E and Uchiyama Y (1999) Regulation of a novel pathway for cell death by lysosomal aspartic and cysteine proteinases. Neuroscience 91: 233-249

30. Castino R, Pace D, Demoz M, Gargiulo M, Ariatta C, Raiteri E and Isidoro C (2002) Lysosomal proteases as potential targets for the induction of apoptotic cell death in human neuroblastomas. Int. J. Cancer 97: 775-779

31. Wang F, Duan R, Chirgwin J and Safe SH (2000) Transcriptional activation of cathepsin D gene expression by growth factors. J. Mol. Endocrinol. 24: 193202

32. Ikeguchi M, Sakatani T, Ueta T, Fukuda K, Oka S, Hisamitsu K, Yamaguchi K, Tsujitani S and Kaibara N (2002) Correlation between cathepsin D expression and p53 protein nuclear accumulation in oesophageal squamous cell carcinoma. J. Clin. Pathol. 55: 121-126

33. Fanning E and Knippers R (1992) Structure and function of simian virus 40 large tumor antigen. Annu. Rev. Biochem. 61: 55-85

34. Tiemann F and Deppert W (1994) Stabilization of the tumor suppressor p53 during cellular transformation by simian virus 40 : influence of viral and cellular factors and biological consequences. J. Virol. 68: 2869-2878

35. Ludlow JW (1993) Interactions between SV40 large-tumor antigen and the growth suppressor proteins $p R b$ and p53. FASEB J. 7: 866-871

36. Jaffrézou JP, Levade T, Bettaieb A, Andrieu N, Bezombes C, Maestre N, Vermeersch S, Rousse A and Laurent G (1996) Daunorubicin-induced apoptosis: triggering of ceramide generation through sphingomyelin hydrolysis. EMBO J. 15: 2417-2424

37. Andrieu-Abadie N, Jaffrézou JP, Hatem S, Laurent G, Levade T and Mercadier JJ (1999) L-carnitine prevents doxorubicin-induced apoptosis of cardiac myocytes: role of inhibition of ceramide generation. FASEB J. 13: 1501-1510

38. Roberg K and Ollinger K (1998) Oxidative stress causes relocation of the lysosomal enzyme cathepsin $\mathrm{D}$ with ensuing apoptosis in neonatal rat cardiomyocytes. Am. J. Pathol. 152: 1151-1156

39. Kagedal K, Zhao M, Svensson I and Brunk UT (2001) Sphingosine-induced apoptosis is dependent on lysosomal proteases. Biochem. J. 359: 335-343

40. Heinrich $M$, Wickel $M$, Schneider-Brachert W, Sandberg C, Gahr J, Schwandner R, Weber T, Saftig P, Peters C, Brunner J, Kronke M and Schutze S (1999) Cathepsin D targeted by acid sphingomyelinase-derived ceramide. EMBO J. 18: 5252-5263

41. Ségui B, Bezombes $C$, Uro-Coste $E$, Medin JA, Andrieu-Abadie N, Aug N, Brouchet A, Laurent G, Salvayre R, Jaffrézou JP and Levade T (2000) Stressinduced apoptosis is not mediated by endolysosomal ceramide. FASEB J. 14: $36-47$
42. Brunk UT, Neuzil J and Eaton JW (2001) Lysosomal involvement in apoptosis. Redox Rep. 6: 91-97

43. Bursch W (2001) The autophagosomal-lysosomal compartment in programmed cell death. Cell Death Differ. 8: 569-581

44. von Figura K, Hasilik A, Pohlmann R, Braulke T, Lemansky P and Stein M (1987) Mutations affecting transport and stability of lysosomal enzymes. Enzyme 38: 144-153

45. Kidd VJ, Lahti JM and Teitz T (2000) Proteolytic regulation of apoptosis. Semin. Cell Dev. Biol. 11: 191-201

46. Saftig P, Hetman M, Schmahl W, Weber K, Heine L, Mossmann H, Koster A, Hess B, Evers M, von Figura K and Peters C (1995) Mice deficient for the lysosomal proteinase cathepsin $D$ exhibit progressive atrophy of the intestinal mucosa and profound destruction of lymphoid cells. EMBO J. 14: 3599-3608

47. Nakanishi $H$, Zhang J, Koike $M$, Nishioku $T$, Okamoto $Y$, Kominami $E$, von Figura K, Peters C, Yamamoto K, Saftig P and Uchiyama Y (2001) Involvement of nitric oxide released from microglia-macrophages in pathological changes of cathepsin D-deficient mice. J. Neurosci. 21: 7526-7533

48. Koike M, Shibata M, Ohsawa Y, Nakanishi H, Koga T, Kametaka S, Waguri S, Momoi T, Kominami E, Peters C, Figura K, Saftig P and Uchiyama Y (2003) Involvement of two different cell death pathways in retinal atrophy of cathepsin D-deficient mice. Mol. Cell. Neurosci. 22: 146-161

49. Rakoczy PE, Zhang D, Robertson T, Barnett NL, Papadimitriou J, Constable IJ and Lai CM (2002) Progressive age-related changes similar to age-related macular degeneration in a transgenic mouse model. Am. J. Pathol. 161: 15151524

50. Berchem G, Glondu M, Gleizes M, Brouillet JP, Vignon F, Garcia M and Liaudet-Coopman E (2002) Cathepsin-D affects multiple tumor progression steps in vivo: proliferation, angiogenesis and apoptosis. Oncogene 21: 59515955

51. Rochefort $H$ and Liaudet-Coopman $E$ (1999) Cathepsin D in cancer metastasis: a protease and a ligand. Apmis 107: 86-95

52. Glondu M, Liaudet-Coopman E, Derocq D, Platet N, Rochefort $H$ and Garcia M (2002) Down-regulation of cathepsin-D expression by antisense gene transfer inhibits tumor growth and experimental lung metastasis of human breast cancer cells. Oncogene 21: 5127-5134

53. Partanen S, Storch S, Loffler HG, Hasilik A, Tyynela J and Braulke T (2002) A replacement of the active site aspartic acid residue-293 in mouse cathepsin $D$ affects its intracellular stability, processing, and transport in HEK 293 cells. Biochem. J. 369: 55-62

54. Glondu M, Coopman P, Laurent-Matha V, Garcia M, Rochefort H and Liaudet-Coopman E (2001) A mutated cathepsin-D devoid of its catalytic activity stimulates the growth of cancer cells. Oncogene 20: 6920-6929

55. Stoka V, Turk B, Schendel SL, Kim TH, Cirman T, Snipas SJ, Ellerby LM, Bredesen D, Freeze H, Abrahamson M, Bromme D, Krajewski S, Reed JC, Yin $X M$, Turk V and Salvesen GS (2001) Lysosomal protease pathways to apoptosis. Cleavage of bid, not pro-caspases, is the most likely route. J. Biol. Chem. 276: 3149-3157

56. De Stefanis D, Reffo P, Bonelli G, Baccino FM, Sala G, Ghidoni R, Codogno P and Isidoro $C$ (2002) Increase in ceramide level alters the lysosomal targeting of cathepsin D prior to onset of apoptosis in HT-29 colon cancer cells. Biol. Chem. 383: 989-999

57. Terman A, Neuzil J, Kagedal K, Ollinger K and Brunk UT (2002) Decreased apoptotic response of inclusion-cell disease fibroblasts: a consequence of lysosomal enzyme missorting? Exp. Cell Res. 274: 9-15

58. Guicciardi ME, Deussing J, Miyoshi H, Bronk SF, Svingen PA, Peters C, Kaufmann SH and Gores GJ (2000) Cathepsin B contributes to TNF-alphamediated hepatocyte apoptosis by promoting mitochondrial release of cytochrome c. J. Clin. Invest. 106: 1127-1137

59. Schotte P, Declercq W, Van Huffel S, Vandenabeele P and Beyaert R (1999) Non-specific effects of methyl ketone peptide inhibitors of caspases. FEBS Lett. 442: $117-121$

60. Fujimoto K, Yamamoto T, Kitano T and Abe S (2002) Promotion of cathepsin L activity in newt spermatogonial apoptosis induced by prolactin. FEBS Lett. 521: $43-46$

61. Chatelut M, Harzer K, Christomanou H, Feunteun J, Pieraggi MT, Paton BC, Kishimoto Y, O'Brien JS, Basile JP, Thiers JC, Salvayre R and Levade T (1997) Model SV40-transformed fibroblast lines for metabolic studies of 
human prosaposin and acid ceramidase deficiencies. Clin. Chim. Acta 262: $61-76$

62. Denizot F and Lang R (1986) Rapid colorimetric assay for cell growth and survival. Modifications to the tetrazolium dye procedure giving improved sensitivity and reliability. J. Immunol. Methods 89: 271-277

63. Folch J, Lees M and Sloane Stanley GH (1957) A simple method for the isolation and purification of total lipids from animal tissues. J. Biol. Chem. 226: 497-509
64. Van Veldhoven PP, Matthews TJ, Bolognesi DP and Bell RM (1992) Changes in bioactive lipids, alkylacylglycerol and ceramide, occur in HIV-infected cells. Biochem. Biophys. Res. Commun. 187: 209-216

65. Mason RW, Green GD and Barrett AJ (1985) Human liver cathepsin L. Biochem. J. 226: 233-241

66. Little L, Alcouloumre M, Drotar AM, Herman S, Robertson R, Yeh RY and Miller AL (1987) Properties of $\mathrm{N}$-acetylglucosamine 1-phosphotransferase from human lymphoblasts. Biochem. J. 248: 151-159 